\title{
MIR373 wt Allele
}

National Cancer Institute

\section{Source}

National Cancer Institute. MIR373 wt Allele. NCI Thesaurus. Code C82191.

The human MIR373 wild-type allele is located in the vicinity of 19q13.41 and is approximately 68 bases in length. This allele, which encodes MIR373 pre-miRNA, plays a role in the regulation of gene expression. Alteration in the expression of this gene is associated with development of testicular germ cell tumor and breast cancer. 